\title{
EXPENDITURE ON THE HEALTHCARE SYSTEM IN UKRAINE IN THE CONTEXT OF IMPROVING THE QUALITY OF PROVISION OF MEDICAL SERVICES
}

\author{
В. В. Матвіїв, \\ аспірант, Ауцький національний технічний університет, м. Ауцьк
}

\author{
ВИТРАТИ НА СИСТЕМУ ОХОРОНИ ЗАОРОВ'Я В УКРАЇНІ В КОНТЕКСТІ ПІАВИЩЕННЯ \\ ЯКОСТІ НАААННЯ МЕАИЧНИХ ПОСАУГ
}

The article provides a theoretical review and critical analysis of scientific publications of well-known European and American researchers on issues related to the feasibility of public spending on health care. The dynamics and structure of all health care expenditures in real and nominal prices of 2012 are analyzed, as well as the specific structure of health care expenditures in Ukraine is characterized in the dynamics. An analysis of health care expenditures in hryvnia and dollar equivalent was performed. The dynamics of capital investments in health care is traced, and the dynamics of health care expenditures as a percentage of GDP is calculated. Budget expenditures on health care in Ukraine are analyzed according to their types: expenditures of the state budget on health care, expenditures of the consolidated budget on health care, the share of state budget expenditures on health care to GDP, \%; the share of consolidated budget expenditures on health care to GDP, \%. In the context of reforming the health care system, we analyzed the state budget expenditures on health care according to the sources of distribution of funds, namely the Ministry, the State Service for Medicines and Drug Control, the National Health Service of Ukraine, the medical subvention, a subvention for a pilot project to develop an emergency medical care system in Vinnytsia, Odessa, Poltava, Donetsk, Ternopil oblasts and the city of Kyiv, and a subvention for the reform of regional health care systems in Ukraine, as well as their structure. It was found that health care reform has made it possible to slightly expand expenditure items in connection with new medical needs, in particular for the introduction of new pilot projects in certain regions of Ukraine that require additional funding from the state as a customer of medical services. The study proposes measures for a more constructive dialogue between the Ministry of Health, the Ministry of Finance and the National Health Service of Ukraine to achieve effective interaction and provide quality medical services to the population of Ukraine.

У статті здійснено теоретичний огляд та критичний аналіз наукових публікацій відомихєвропейських та американських дослідників щодо питань, які стосуються доцільності здійснення державних видатків на охорону здоров'я. Проаналізовано динаміку та структуру усіх витрат на охорону здоров'я у реальних та номінальних цінах 2012 року, а також охарактеризовано в динаміці видову структуру витрат на охорону здоров'я в Україні. Здійснено аналіз витрат на охорону здоров'я в гривневому та доларовому еквіваленті. Простежено динаміку капітальних інвестицій на охорону здоров'я, а також обчислено динаміку витрат на охорону здоров'я у відсотко- 
вому співвідношенні до ВВП. Проаналізовано бюджетні витрати на охорону здоров 'я в Україні за їх видами: витрати державного бюджету на охорону здоров'я, витрати зведеного бюджету на охорону здоров'я, частку витрат державного бюджету на охорону здоров'я до ВВП,\%; частку витрат зведеного бюджету на охорону здоров'я до ВВП, \%. В умовах реформування системи охорони здоров'я проведено аналіз видатків державного бюджету на охоронуздоров'я відповідно за джерелами розподілу коштів, а саме Апаратом Міністерства охорони здоров'я, Державною службою лікарських засобів та контролю за наркотиками, Національною службою здоров'я України, за медичною субвенцією, субвенцією на пілотний проєкт щодо розвитку системи екстреної медичної допомоги у Вінницькій, Одеській, Полтавській, Донецькій, Тернопільській областях та м. Києві та субвенцією на реформування регіональних систем охорони здоров'я в Україні, а також охарактеризовано їх структуру. 3 'ясовано, що реформування сфери охорони здоров'я дало можливість дещо розширити статті витрат узв 'язкуз новими потребами медичної сфери, зокрема для запровадження нових пілотних проєктів у певних регіонах України, які потребують додаткового фінансування зі сторони держави як замовника медичних послуг. За результатами дослідження запропоновано заходи щодо більш конструктивного діалогу між Міністерством охорони здоров'я, Міністерством фінансів та Національною Службою здоров'я України для досягнення ефективної взаємодії й надання якісних медичних послуг для населення України.

Key words: public expenditure, health care, medical care, medical services, state policy in the field of health care.

Ключові слова: держаВнівидатки, охорона здоров'я, медична допомога, медичні послуги, державна політика В сфрері охорони здоров'я.

\section{FORMULATION OF THE PROBLEM}

An important prerequisite for the effective development of health care in Ukraine is the availability of a sufficient level of state funding for health care institutions and the direction and involvement of appropriate financial resources in the development of the medical sector, which, in its turn, will assist to the formation and improvement of health services quality in health care institutions of Ukraine.

Measures for attracting capital investment in health care are extremely necessary given the complex set of problems in the industry which need to be resolved with the assistance of the state. Among them are the need to purchase and upgrade medical equipment for health care institutions, the organization and implementation of research results in the field of medicine, the development of health and prevention programs, social guarantees of free medical services, social protection of health care workers, etc.

Paying attention to the low level of state expenditures for direct use by health care institutions which occasionally provoked crises phenomena (depreciation of fixed assets of health care institutions, low level of medical services, low level of salaries of medical workers, "outflow" of medical personnel abroad, etc.), the state had to start reforming this area, one of the goals of which was to increase sources of funding and their targeted use for specific needs.

The initiated reform of the health care system in Ukraine was aimed primarily at solving the problem of providing equal access to qualitative medical services through the introduction of a new principle of funding, defined as "money follows the patient" [17]. This mechanism, introduced in the process of reforming the primary link of medical institutions, assisted in gradual establishment of a civilized relationship "doctor patient", allowed to ensure a sufficient level of funding for health care institutions, to increase significantly the salaries of health workers, allowed to provide a sufficient level of funding for health care institutions. Incomplete reform of the health care system in Ukraine at the secondary and tertiary links again becomes actual, especially in modern conditions of the global pandemic COVID-19, the problem of sufficient funding for the branch as a guarantee of improving the quality of medical services and saving the lives of the population.

\section{THE ANALYSIS OF RECENT RESEARCHES AND PUBLICATIONS}

Much research by foreign scholars are devoted to the development of proposals concerning effectiveness of public spending on health care. In particular, American scientists from the Finance Department of the International Monetary Fund (Gupta et al, 2003) in a conducted study of public spending on health care in 70 countries, argue that there is a relationship between the state of health of the poorest layers of the population and the level of public health care costs for the population. They determined that even a small increase in government spending on health care in the countries studied had a positive effect on the poor population [25]. Indian researchers (Farahani et al, 2011) note that increased government spending on health has a significant impact on reducing mortality in India for almost all age groups, regardless of age categories [24].

American researchers from the University of Cambridge (Budhdeo at al, 2015) conducted a multichoice regression analysis of the three European Union countries (Greece, Portugal, Ireland) that have suffered the most 
from the global financial crisis. In order to receive EU financial support to repay public debt, these countries had to reduce public spending on health care. At the same time, as American researchers have shown, reducing government spending by even 1 per cent significantly increased the mortality rate in both the short and long term perspective [23].

In this context, it is difficult to agree with the discussion thesis of researchers from the Department of Cash and Capital Markets of the International Monetary Fund (Jafarov and Gunnarsson, 2008); that the level of public spending on health care in Croatia is too high, so, in their opinion, it can be significantly reduced, which will not adversely affect the health system and general health of the population [25]. A senior researcher at the Center for Global Development in Washington (Savedoff, W. 2007) believes that health care funding of 5-10 per cent of GDP is necessary and appropriate to reduce mortality [26].

A senior researcher at the Center for Global Development in Washington, D.C. (Savedoff, W. 2007), contrary to, emphasizes that funding for health care at the level of $5-10 \%$ of GDP is necessary and appropriate to reduce mortality [27].

Analyzing the increase in health care costs in California over the past twenty-five years from 14 to 21 percent, American scientists (Tran, LD at al, 2017) grounded the thesis on inefficiency of the use of funds which, in their opinion, should be directed for specific, specialized medical programs for the population. Such funding, in their opinion, can not only be more cost-effective, but also help reduce morbidity, prevention of public health and avoidance of premature deaths [28].

The results of scientific research on the current state of financing of the health care system in Ukraine are reflected in the works of domestic economists A. Akhlamov and N. Kusyk [1], J. Buzdugan [2]. V. Glukhov and V. Krasilnikova [3], M. Bulakh [4], S. Goncharuk, S. Pryimak and L. Danyliak [5], D. Gomon [6], E. Ivanenko [8], D. Karamysheva, O. Vashyeva, A. Nemchenko and B. Volos [9], I. Kohut [10], V. Lekhan, L. Kryachkova and L. Zayarsky [14] K. Pavliuk [16], L. Parkhetova [15], T. Sitash [19], L. Filstein and N. Gokhgolerint [21], M. Shevchenko [22] and others.

However, in modern scientific researches there are a number of little-studied issues regarding the analysis of

Table 1. Dynamics of health care expenditures in real terms in 2012-2017 (in billion hryvnias in 2012 prices)

\begin{tabular}{|c|c|c|c|c|c|}
\hline \multirow[b]{2}{*}{ Years } & \multicolumn{5}{|c|}{ Indicatos } \\
\hline & $\begin{array}{c}\text { General } \\
\text { expenditures } \\
\text { on health }\end{array}$ & $\begin{array}{c}\text { Government } \\
\text { spending }\end{array}$ & $\begin{array}{c}\text { Household } \\
\text { expenditures }\end{array}$ & $\begin{array}{l}\text { Other private } \\
\text { expenditures } \\
\text { (insurance } \\
\text { payments, health } \\
\text { insurance funds, } \\
\text { etc.) }\end{array}$ & $\begin{array}{c}\text { International } \\
\text { assistance }\end{array}$ \\
\hline 2012 & 108,4 & 62,3 & 43,0 & 2,8 & 0,3 \\
\hline 2013 & 115,2 & 65,0 & 46,6 & 3,3 & 0,3 \\
\hline 2014 & 78,8 & 40,8 & 35,7 & 2,1 & 0,2 \\
\hline 2015 & 56,5 & 27,6 & 27,6 & 1,1 & 0,2 \\
\hline 2016 & 56,5 & 25,4 & 29,6 & 1,1 & 0,4 \\
\hline 2017 & 66,9 & 33,2 & 31,8 & 1,3 & 0,6 \\
\hline $\begin{array}{l}2017 \text { in } \\
\text { per cent } \\
2012\end{array}$ & 61,7 & 53,3 & 73,0 & 46,4 & 200,0 \\
\hline
\end{tabular}

Source: compiled by the author on the basis of [13]. the development of capital investment in the medical sector in the context of health care reform in Ukraine.

The purpose of the study is to analyze the dynamics of expenditures on health care in Ukraine as a prerequisite for improving the quality of medical services in terms of reforming the health care system in Ukraine.

\section{PRESENTATION OF THE MAIN MATERIAL}

In modern times, health care costs are of top priority in the world, because the importance of medical spending in every developed country is not in doubt, as it contributes to the formation of the health of the nation, it promotes comprehensive access to possible benefits in society.

We share the opinion of the Director General of the World Health Organization Dr. Tedros Adhanom Ghebreyesus that "...Expenditures of every nation on health protection should not be estimated as a burden on every country's budget, but as an investment in the fight against poverty, a means of increasing productivity, ensuring economic growth and building a healthy, safe and fair society..." [18].

Thus, the priority of health care spending for each state is a vital factor in providing all the necessary conditions for the development of a healthy society. Thus, according to WHO data, the costs of providing medical services in each country is growing every year, in particular in countries with low economic development by 6 per cent, and in developed countries by 4 per cent [18].

On the basis of these data, we can say that the costs of health care both in the world and in Ukraine will tend to increase both in the near future and in further perspective.

Thus, the government policy on health protection should take into account that the increase in the level of costs for health care is an important factor in maintaining the health of citizens, reducing their mortality and increasing life expectancy in the country.

Taking into account the above trends in the growth of health care spending in the world, we must state the fact that these trends are no exception for domestic medicine, which in recent decades is constantly underfunded from the state budget, which does not allow the medical industry to develop at the appropriate level and provide basic needs of the population in medical care.

In Ukraine, we observe an increase in health care expenditures from year to year which reflects global trends which, however, reduce or even prevent the poorest layers of the population from the access to qualitative medical services.

An important and objectively necessary decision of the Government was the launch of medical reform, the aim of which was to improve funding in the field of medical care for provision of all layers of the population with the most necessary medical services. As a result, in 2017, the Law of Ukraine "On State Financial Guarantees of Medical Care of the Population" was adopted.

Considering the dynamics of health care expenditures in Ukraine for the period from 2012 to 2017 in real 2012 prices, we observe a similar situation with global 
trends in Ukraine, where the level of health care expenditures is growing from year to year in nominal terms, and in reality, on the contrary, it is declining, which is a kind of indicator of such economic phenomena as the growth of inflation processe in the state economy, decrease of living standards with simultaneous decrease of incomes and social function of the state to provide necessary medical care and qualitative medical services to the poorest layers of the population.

This is an evidence of a decrease in government spending on health care in Ukraine in 2017 compared to 2012 by more than a third, which clearly shows the negative dynamics of reducing government spending on health care in the country as a whole (Table 1).

In the specific structure of health care expenditures, government expenditures, household expenditures and other private expenditures which include insurance payments, payments from health insurance funds and international assistance from other states play an important role.

Among all types of health care expenditures, the most significant share is government spending on this service sector the amount of which ranges from 44.0 to 57.0 per cent, the costs of patients from their own pockets for medical services which range from 39.0 to 52.4 per cent and the remainder is a small percentage of expenditures which comprise other private expenditures ranging from 1.9 to 2.6 per cent over the past six years, with international assistance from other countries ranging from 0.3 to 0,9 percent.

During the analyzed period, there is a decrease in public spending on health care in 2017 compared to 2012 by 46.7 percent. These trends characterize that a significant part of expenditures "fall on the shoulders" of citizens who receive different in amount incomes and do not always have the opportunity to cover various expenses, including medical services from their family budget, and the targeted assistance for citizens which is applied in the developed European countries with socially-oriented economies, has not been embodied in the state policy of Ukraine.

During the analyzed period, the decrease in public spending on health care in 2017 compared to 2012 by 46.7 per cent takes place. These trends characterize that a significant part of the costs "fall on the shoulders" of citizens who receive different incomes and do not always have the opportunity to cover various expenses, including medical services from their family budget, and targeted assistance for citizens which has application in developed European countries with socially-oriented economies did not find its embodiment in the state policy of Ukraine..

In Ukraine, for the last twenty-five years after the declaration of independence, the model of financing health care institutions has not been developed which de facto did not allow citizens to receive the necessary package of medical services because in accordance with the provisions of the Basic Law of Ukraine, the Constitution of Ukraine, in particular in Article 49, there is a clear definition of the state funding for health care, which accordingly stipulates that in Ukraine "...health care is provided by the state funding of relevant social and economic, medicosanitary and health prevention programs" [11].

Therefore, according to the current legislation, the responsibilities of the state include ensuring every citizen, regardless of his financial capabilities, the right to decent financial medical care. Thus, Article 49 of the Constitution of Ukraine stipulates that the priorities of the state include "creating conditions for effective and accessible medical care to all citizens" [11].

This article declares free treatment for all categories of citizens of Ukraine, in particular, it states that "... in state and municipal health care institutions medical care is provided free of charge; the existing network of such establishments cannot be reduced. The state assists the development of medical institutions of all forms of ownership" [11].

Paying attention to the above interpretation, we can say that according to the Constitution of Ukraine, the health care system in Ukraine for the last quarter of a century was de jure considered free of charge, but in fact, there were de facto shadow schemes of payment of patients to medical staff for the given medical.

A significant share of funds for treatment in communal and state-owned medical institutions was covered at the expense of the patients themselves who were admitted for treatment, as the health care sector was not funded at the appropriate level. Thus, the costs of patients for medical care over the past six years, respectively, increased from 39.7 per cent in 2012 to 47.5 per cent in 2017 , and in 2016 - the level of patients' spending on health care reached 52.4 per cent which comprise a large proportion of the costs spent by patients on medical treatment.

In regard of other health care expenditures, a small share of them is occupied by the costs of insurance payments and payments from health insurance funds, which are relatively small and miserable (their level ranges from 1.6 to $2.9 \%$ ), as well as a small percentage in the general specific structure of health care expenditures is occupied by international assistance, which hospitals receive from international charitable organizations in the form of humanitarian aid (from 0.3 to $0.9 \%$ ). 
Table 3. State expenditures on health care in Ukraine in real hryvnia in 2018 and in US dollars in 2010-2018

\begin{tabular}{|c|c|c|c|c|c|c|}
\hline \multirow{3}{*}{ Years } & \multicolumn{6}{|c|}{ Indicatos } \\
\hline & \multirow{2}{*}{$\begin{array}{c}\text { Total } \\
\text { mln. } \\
\text { hryvnias }\end{array}$} & \multicolumn{2}{|c|}{ Growth rate up to } & \multirow{2}{*}{$\begin{array}{c}\text { Total } \\
\text { mln. } \\
\text { hryvnias }\end{array}$} & \multicolumn{2}{|c|}{ Growth rate up to } \\
\hline & & $\begin{array}{c}\text { preceding } \\
\text { year }\end{array}$ & $\begin{array}{c}\text { till } \\
2010\end{array}$ & & $\begin{array}{c}\text { preceding } \\
\text { year }\end{array}$ & $\begin{array}{c}\text { till } \\
2010\end{array}$ \\
\hline 2010 & 1920 & $\mathrm{x}$ & $\mathrm{x}$ & 242 & $\mathrm{x}$ & $x$ \\
\hline 2011 & 2113 & 110,1 & 110,1 & 265 & 109,5 & 109,5 \\
\hline 2012 & 2707 & 128,1 & 141,0 & 339 & 127,9 & 140,1 \\
\hline 2013 & 1746 & 64,5 & 90,9 & 218 & 64,3 & 90,1 \\
\hline 2014 & 1224 & 70,1 & 63,8 & 103 & 47,2 & 42,6 \\
\hline 2015 & 2367 & 193,4 & 123,3 & 109 & 105,8 & 45,0 \\
\hline 2016 & 4479 & 189,2 & 233,3 & 175 & 160,6 & 72,3 \\
\hline 2017 & 6708 & 149,8 & 349,4 & 252 & 144,0 & 104,1 \\
\hline 2018 & 8139 & 121,3 & 423,9 & 299 & 118.7 & 123,6 \\
\hline
\end{tabular}

Source: compiled by the author on the basis of [13].

Table 4. Analysis of budget expenditures on health care in Ukraine in 2011-2018

\begin{tabular}{|l|c|c|}
\hline \multirow{2}{*}{ Indicatos } & \multicolumn{2}{c|}{ Years } \\
\cline { 2 - 3 } & 2011 & 2018 \\
\hline $\begin{array}{l}\text { Consolidated budget expenditures on health } \\
\text { care, UAH million }\end{array}$ & 48,96 & 115,85 \\
\hline $\begin{array}{l}\text { State budget expenditures on health care, UAH } \\
\text { million }\end{array}$ & 10,22 & 22,62 \\
\hline $\begin{array}{l}\text { Share of state budget expenditures on health } \\
\text { care to GDP, per cent }\end{array}$ & 3,8 & 3,3 \\
\hline $\begin{array}{l}\text { Share of consolidated budget expenditures on } \\
\text { health care to GDP, per cent }\end{array}$ & 11,6 & 9,3 \\
\hline
\end{tabular}

Source: compiled by the author on the basis of [16].

Thus, according to the conducted costs analysis, health care costs were reduced in real prices, and many health care costs were done by patients themselves, who were not always satisfied with the quality of these services.

Analyzing the dynamics of all expenditures on health care in Ukraine in 2002-2017 (in nominal terms of 2012 prices), the increase in health care expenditures in Ukraine over these years has been clearly traced which is connected, in the first turn, with inflationary processes in the state and increasing of the costs of medical services (table 2).

According to Table 2 data, expenditures on health care in 2017 compared to 2012 amounted to $205.4 \%$, respectively, public expenditures on health care increased and their level was $177.3 \%$. There is a significant increase in private household expenditures on health care, where their level was $246.1 \%$ which is a clear and reliable evidence of price rising for medical services and the mismatch between state financial expenditures on health care.

Concerning the dynamics of public spending on health care in 2010-2018, there is a certain relationship between a significant reduction in public spending by 2013-2014 which is associated with the beginning of Russia's military aggression in eastern Ukraine which, in turn, caused a significant depreciation of the national currency and the redistribution of state expenditures for military purposes (Table 3).

Thus, over the last almost two decades we have seen a positive trend in the growth of public spending in Ukraine on health care, namely the growth of health care spending occurs from 2010 to 2012 by $10.1 \%$ and $28.1 \%$ and $9.5 \%$ and $27.9 \%$, respectively which is expressed in the growth of expenditures to the previous year in both hryvnia and dollar equivalents.

As for the growth rates of health care expenditures to the base year 2010, in 2010-2012, the trend remains almost identical, as evidenced by the growth of $10.1 \%$ and $41.0 \%$ of health care expenditures in hryvnia equivalent and by $9.5 \%$ and $40.1 \%$, respectively in dollar equivalent.

Negative phenomena in the field of health care financing are observed in the period from 2013 to 2015 when there was a significant reduction in state spending on health care in both national and foreign currencies, and this indicates an increase in the crisis in the economy. This is largely due to the outbreak of military operations and Russia's aggression in eastern Ukraine which has caused significant problems with health care financing and the intensification of crisis in the country's economy.

Beginning with 2013, state spending on health care in Ukraine has fallen sharply, and this is clearly shown in Table 1. For the period from 2013 till 2015, there was a significant reduction in health care spending in Ukraine. Thus, in percentage correlation, the growth rates of state health expenditures in the national currency in 2013 and 2014 compared to the previous period were $64.5 \%$ and $70.1 \%$ in hryvnia and $64.3 \%$ and $47.2 \%$ in US dollars. This is a clear example of the fact that in 2013-2014 there was a sharp reduction in state spending on health care which did not favor strengthening the health care system in Ukraine but deepened the long-standing unresolved problems in the branch.

The devaluation and fall of the national currency in Ukraine more than three times during the analyzed period became the catalyst for the fall of the national economy which is manifested in a decrease in the level of imports of products, reducing the situation on the domestic market. These negative phenomena in the economy, accordingly, lead to a decline in competitiveness of the national economy in general and also, in its turn, to impoverishment of the population, and insufficient state funding assists in the formation of the lack of access to qualitative health services.

Thus, the growth of public spending on health care is, on the one hand, a positive indication of the state's provision of basic health care spending, and on the other hand, these expenditures on the medical sector are quite small in dollar terms, which again gives us reason to summarize the public funding of this industry at an insufficient level.

Thus, the increase in state spending on health care is, on the one hand, a positive evidence concerning the provision of basic health care spending by the state, and on the other hand, these expenditures on the medical sector are quite small in dollar terms, which again gives us a reason to summarize the state funding of this branch at an insufficient level.

Financing of health care institutions should become an urgent and an important priority for the development of every developed country in the world and very important in this direction is budget expenditures for health care by the state which plays an important role. 
ЕКОНОМІЧНА НАУКА

A comparative analysis of budget Table 5. Analysis of state budget expenditures on health care expenditures on health care in Ukraine in 2011-2018 is considered in Table 4.

Analyzing and comparing the consolidated and state budget expenditures on health care which were spent from 2011 till 2018 , we can clearly see that the level of consolidated budget expenditures in 2018 is 2.4 times higher than in 2011 , but this is not a positive achievement, as it should be understood that in dollar terms, this amount in 2018 is much less than that was sent for health care in 2011.

A similar tendency is also observed concerning the ratio of the share of state budget expenditures to the consolidated budget expenditures of the health sector in Ukraine where their amount comprised 22.9 per cent respectively of all in 2018-2019

\begin{tabular}{|c|c|c|c|c|}
\hline & \multicolumn{4}{|c|}{ Роки } \\
\hline & \multicolumn{2}{|c|}{2018} & \multicolumn{2}{|c|}{2019} \\
\hline & $\begin{array}{c}\text { Total } \\
\text { billion } \\
\text { hryvnias }\end{array}$ & $\begin{array}{c}\text { Structure, } \\
\text { per cent }\end{array}$ & $\begin{array}{c}\text { Total } \\
\text { billion } \\
\text { hryvnias }\end{array}$ & $\begin{array}{c}\text { Structure, } \\
\text { per cent }\end{array}$ \\
\hline The staff of the ministry & 18,2 & 20,9 & 17,9 & 18,7 \\
\hline $\begin{array}{l}\text { State Service for Medicines and Drug } \\
\text { Control }\end{array}$ & 0,1 & 0,1 & 0,1 & 0,1 \\
\hline National Health Service of Ukraine & 8,3 & 9,6 & 19,3 & 20,2 \\
\hline Medical subvention & 57,4 & 66,1 & 55,4 & 57,9 \\
\hline $\begin{array}{l}\text { Subvention for a pilot project on the } \\
\text { development of the emergency medical } \\
\text { care system in Vinnytsia, Odesa, } \\
\text { Poltava, Donetsk, Ternopil regions and } \\
\text { the city of Kyiv }\end{array}$ & - & - & 0,9 & 0,9 \\
\hline $\begin{array}{l}\text { Subvention for the reform of regional } \\
\text { health care systems }\end{array}$ & 1,7 & 1,9 & 1,5 & 1,6 \\
\hline Others & 1,2 & 1,4 & 0,6 & 0,6 \\
\hline
\end{tabular}

Source: compiled by the author on the basis of [16]. expenditures in the consolidated budget for the medical sector. This, in fact, is the evidence that expenditures from the state budget for the medical sector are quite miserable. As for the share of consolidated budget expenditures on health care in GDP, their level was 11.6 per cent in 2011 , and in $2018-$ 9.3 per cent, which is 2.3 percentage points less; the share of consolidated budget expenditures in 2011 was 3.8 per cent, and in $2018-3.3$ per cent, which indicates a decrease of 0.5 per cent point.

Thus, the analysis of consolidated and state budget expenditures and the share of these expenditures in GDP gives us the reason to say that the level of consolidated and state budget expenditures is not high, and their share of health care as a percentage of GDP has tended to decrease over the analyzed years, which became an unfavorable factor for receiving qualitative and full medical care for the population.

An important stage in the development of health care was the beginning of the reform of the branch in Ukraine in 2017 which assisted in the transition from July 2018 to completely new methods of financing the health care system - the direction of "funds should follow the patient" which was aimed at reduction of excessive household expenditures.

Health care reform was planned to be implemented with the reform of three sectors of medicine in three stages: primary link and emergency medicine, secondary link of medicine and tertiary link of medicine.

Very important is the study of the analysis of state budget expenditures on health care in 2018-2019 (Table 5).

Among the state budget expenditures on health care in 2018 , the leading place is occupied by medical subventions received by medical institutions from the state budget, the level of which was $66.1 \%$ in 2018 and in 2019 their share decreased to $57.9 \%$.

Expenditures of the Ministry of Health Care of Ukraine decreased from UAH 18.2 billion in 2018 to UAH 17.9 billion in 2019 which was reflected in the overall structure of state budget expenditures by the decrease from $20.9 \%$ to $18.7 \%$.

In connection with the reform of the health care system, the second place in the expenditure item in 2019 is

occupied by the financing of primary and emergency medicine which takes place through the National Health Service of Ukraine. In the structure of the state budget expenditures, the share of funding for medical institutions by the National Health Service of Ukraine increased from 9.6 per cent in 2018 to 20.2 per cent in 2019.

The remaining expenditure items of health care expenditures in 2018 were such expenditures as the subvention for the reform of regional health care systems which accounted for 1.9 per cent of the total structure of health expenditures, and other expenditures comprised 1.4 per cent. In 2019, in addition to the above-mentioned items of expenditures, an additional subvention was introduced for a pilot project to develop an emergency medical care system in Vinnytsia, Odesa, Poltava, Donetsk, Ternopil regions and the city of Kyiv in the amount of UAH 0.9 billion ( 0.9 per cent); at the same time, the subvention for the reform of regional health care systems accounted for 1.6 per cent, and other expenditures -0.6 per cent.

As a result of the analysis of all items of health care expenditures, we can say that the reform of the branch has made it possible to expand the costs of expenditure items in connection with the new needs of the medical sector in implementing and financing pilot projects for certain regions that needed additional funding from the state as a customer of medical services.

\section{CONCLUSIONS}

Summarizing the conducted research, we can conclude that in Ukraine over the past decade there have been a number of problems in the field of health care, namely:

1) increase in the cost of medical services expenditures for which patients had to pay themselves from the family budget;

2) low level of state funding in the conditions of inflation processes and the constant rise of expenditures on medicine has led to the decrease in the quality of rendering medical services to patients;

3) The decrease in the dynamics of expenditures, as well as the share of consolidated and state budget expenditures on health care in relation to GDP in Ukraine was a reflection of the negative phenomena in the state economy. 
The introduction of health care financing in 2018 through the National Health Service of Ukraine has allowed the health care sector to receive increased funding in 2019 more than twice.

Thus, an important factor in the development of health care in Ukraine should be open and close communication between public, state health care institutions, private physicians who practice privately and provide these services to patients, and the National Health Service of Ukraine, the Ministry of Health Care on the implementation of secondary and tertiary link reforms in medicine where the main emphasis should be on providing qualitative medical care to each patient, attached in an electronic declaration to a particular medical professional.

\section{Література:}

1. Ахламов А.Г., Кусик Н.Л. Економіка та фрінансування охорони здоров'я: Одеса: ОРІДУ НАДУ, 2011. 134 с.

2. Буздуган Я. Поняття, принципи, форми фрінансового забезпечення охорони здоров'я в Україні. Віче. 2008. № 9-10. С. 26-28.

3. Глухов В.І., Красільнікова В.Ю. Проблеми фрінансового забезпечення системи охорони здоров'я України. Вісник КДПУ імені Михайла Остроградського. 2009. Вип. 2. (55). Ч. 1. С. 108-112.

4. Глухов В.І., Булах М.О. Джерела фрінансового забезпечення системи охорони здоров'я в Україні Гроші, фрінанси і кредит. № 10. 2016. С. 760-764.

5. Гончарук С.М., Приймак С.В., Даниляк Л.А. Сучасний стан і проблеми фрінансування установ охорони здоров'я в Україні Бізнес інфрорм. № 1. 2016. С. 190-194.

6. Гомон Д.О. Проблеми фрінансування сорери охорони здоров'я в Україні Південноукраїнський правовий часопис. № 3 (40) 2014. С. 124-126.

7. Досвід країн Європи у фрінансуванні галузі охорони здоров'я. Уроки для України / за заг. ред. В.Г. Черненка та В.М. Рудого. Київ: Академпрес, 2002. 112 с.

8. Іваненко Є. Фінансове забезпечення охорони здоров'я в умовах соціально-економічних трансформацій. Світ фрінансів. 2015. Вип. 3. С. 71-81.

9. Карамишев Д.В., Вашєв О.Є., Немченко А.С., Волос Б.О. Державна політика фрінансування галузі охорони здоров'я в Україні. URL: http://www.kbuapa.kharkov.ua/e-book/db/2007-1-1/doc/2/02.pdf

10. Когут І.А. Проблеми та перспективи фрінансування системи охорони здоров'я. Збірник наукових праць Таврійського державного агротехнологічного університету (Економічні науки). 2013. № 1 (1). С. 248-257. URL: http://nbuv.gov.ua/UJRN/znptdau_2013_1_1_32

11. Конституція України (Відомості Верховної Ради України (BBP), 1996, № 30, ст. 141). URL: https:// zakon.rada.gov.ua/laws/show $/ 254 \%$ D0\%BA/96\%D0\%B2\%D1\%80\#Text

12. Лехан В.М., Крячкова Л.В, Заярський Л.В Аналіз реформ охорони здоров'я в Україні: від здобуття незалежності до сучасності, Україна. Здоров'я нації. 2018. № 4 (52).

13. Офріційний сайт Державної служби статистики України URL: http://www.ukrstat.gov.ua/

14. Павлюк К.В. Фінансування охорони здоров'я як складової людського капіталу. Формування ринкових відносин в Україні. 2006. № 9. С. 143-148.
15. Пархетова Л. В. Методи фінансового забезпечення охорони здоров'я в Україні. Міжнародний науковий журнал "Інтер наука". Серія. Економічні науки. 2018. № 2 (10). С. $39-45$.

16. Проект USAID "Трансформація фрінансового сектору": можливості для лізингу медичного обладнання в Україні дослідження ринку. Грудень 2019 р. URL: http: / /www.fst-ua.info/wp-content/uploads/2019/12/ Leasing-Medical-Equipment_Survey_dec2019_ua.pdf

17. Ресрорма системи охорони здоров'я. Урядовий портал. URL: https://www.kmu.gov.ua/diyalnist/ reformi/rozvitok-lyudskogo-kapitalu/reforma-sistemiohoroni-zdorovya

18. Рівень медицини як важіль сталого розвитку суспільства URL: http://www.dut.edu.ua/ua/news-1-8276878-riven-medicini-yak-vazhil-stalogo-rozvitku-suspilstva

19. Сіташ Т.Д. Фінансування системи охорони здоров'я в Україні: тенденції та рефрормування. Механізм регулювання економіки. 2012. № 1. С. 164-169.

Україна: огляд рефрорми фрінансування системи охорони здоров'я 2016-2019. 20. Спільний звіт ВООЗ та Світового банку. Україна: огляд рефрорми фрінансування системи охорони здоров'я 2016-2019. URL: http:/ /www.euro.who.int/_data/assets/pdf_file/0018/ $425340 /$ WHO-WB-Joint-Report_UKR_Fullreport_Web.pdf

21. Фільштейн Л.М., Гохголеринт Н.Л. Проблемні питання фрінансування галузі охорони здоров'я. Наукові праці Кіровоградського національного технічного університету. Економічні науки. 2011. № 20 (ч. 1). URL: http://www.nbuv.gov.ua/Portal/natural/Npkntu_e/ 2011_20_1/stat_20_1/58.pdf

22. Шевченко М.В. Загальні витрати на охорону здоров'я в Україні (за даними національних рахунків охорони здоров'я) Україна. Здоров'я нації. 2010. 2 (14). C. 84-88.

23. Budhdeo S., Watkins J., Atun R., Williams C., Zeltner T., \& Maruthappu M. (2015). Changes in government spending on healthcare and population mortality in the European union, 1995-2010: a cross-sectional ecological study. Journal of the Royal Society of Medicine, 108 (12), 490-498. https://doi.org/10.1177/0141076815600907

24. Farahani M., Subramanian S.V., \& Canning D. (2010). Effects of state-level public spending on health on the mortality probability in India. Health economics, 19 (11), 1361-1376. https://doi.org/10.1002/hec.1557

25. Gupta S., Verhoeven M. and Tiongson E.R. (2003), Public spending on health care and the poor. Health Economics., 12 (8) 685-696. https://doi.org/10.1002/ hec.759.

26. Jafarov E. and Gunnarsson V. (2008). Government Spending on Health Care and Education in Croatia: Efficiency and Reform Options. IMF Working Paper 08 (136) DOI:10.5089/9781451869958.001

27. Savedoff, W. (2007) What Should A Country Spend On Health Care? Health Affairs 26 (4), 962-970. DOI: https://doi.org/10.1377/hlthaff.26.4.962

28. Tran L.D., Zimmerman F.J., Fielding J.E. (2017). Public health and the economy could be served by reallocating medical expenditures to social programs SSM Population Health. 3 (1). 185- 191. 
References:

1. Akhlamov, A. H. and Kusyk, N. L. (2011), Ekonomika ta finansuvannia okhorony zdorovia [Economics and financing of health care], ORIDU NADU, Odessa, Ukraine.

2. Buzdugan, J. (2008), "Concepts, principles, forms of financial support of health care in Ukraine", Viche, vol. $9-10$, pp. $26-28$.

3. Hlukhov, V. I. and Krasilnikova, V. Y (2009), "Problems of financial support of the health care system of Ukraine", Visnyk Kyivskoho derzhavnoho pedahohichnoho universytetu imeni Mykhaila Ostrohradskoho, vol. 2 (55), pp. 108-112.

4. Hlukhov, V. I. and Bulakh, M. O. (2016), "Sources of financial support of the health care system in Ukraine", Hroshi, finansy ta kredyt, vol. 10, pp. 760-764.

5. Honcharuk, S. M. Pryimak, S. V. and Danyliak, L. A. (2016), "Current state and problems of financing health care institutions in Ukraine", Biznes inform, vol. 1, pp. $190-194$.

6. Homon, D. O. (2014), "Problems of financing the sphere of health care in Ukraine", Pivdennoukrainskyi pravovyi chasopys, vol. 3 (40), pp. 124-126.

7. Chernenko, V. H. and Rudyi, V. M. (2002), Dosvid krain Yevropy u finansuvanni haluzi okhorony zdorovia. Uroky dlia Ukrainy [Experience of European countries in financing health care. Lessons for Ukraine], Akadempres, Odessa, Ukraine.

8. Ivanenko, E. (2015), "Financial provision of health care in the conditions of social and economic transformations", Svit finansiv, vol. 3, pp. 71-81.

9. Karamishev, D. V. Vashev, O. E. Nemchenko, A. S. and Volos, B. O. (2007), "State policy of financing the healthcare sector in Ukraine", Derzhavne budivnytstvo, vol. 1, available at: http://www.kbuapa.kharkov.ua/ebook/db/2007-1-1/doc/2/02.pdf (Accessed 5 June 2020).

10. Kohut, I. A. (2013), "Problems and prospects of financing the health care system", Zbirnyk naukovykh prats Tavriiskoho derzhavnoho ahrotekhnolohichnoho universytetu (Ekonomichni nauky), vol. 1, pp. 248-257, available at: http://nbuv.gov.ua/UJRN/znptdau_2013_1_1_32 (Accessed 8 June 2020).

11. The Verkhovna Rada of Ukraine (1996), "Constitution of Ukraine", available at: https://zakon.rada.gov.ua/laws/show /254\%D0\%BA/96-\%D0\%B2\%D1\%80\#Text

12. Lekhan, V. M., Kryachkova, L. V., Zayars'kyy, L. V. (2018), "Analysis of health care reforms in Ukraine: from independence to modern", Ukraina. Zdorovia natsii, vol. 4 (52), pp. 5-11.

13. Official site of the State Statistics Service of Ukraine (2020), available at: http:/ / www.ukrstat.gov.ua/ (Accessed 10 June 2020).

14. Pavlyuk, K.V. (2006), "Financing of health care as a component of Jewish capital", Formuvannia rynkovykh vidnosyn v Ukraini, vol. 9, pp. 143-148.

15. Parkhetova, L.V.(2018), "Methods of financial support of health care in Ukraine", Mizhnarodnyi naukovyi zhurnal "Inter nauka". Seriia. Ekonomichni nauky, vol.2 (10), pp. $39-45$.
16. USAID (2019), "Financial Sector Transformation" Project: Opportunities for Leasing Medical Equipment in Ukraine. Market Research", available at: http://www.fstua.info/wp-content/uploads/2019/12/LeasingMedical-Equipment_Survey_dec2019_en.pdf (Accessed 1 June 2020)

17. Health care reform (2020), available at: https:// www.kmu.gov.ua/diyalnist/reformi/rozvitok-lyudskogo-kapitalu / reforma-sistemi-ohoroni-zdorovya (Accessed 1 June 2020)

18. State University of Telecommunications (2019), "The level of medicine as a lever of sustainable development of society", available at: http://www.dut.edu.ua/ en/news-1-827-6878-riven-medicini-yak-vazhil-stalogorozvitku-suspilstva (Accessed 8 June 2020)

19.Sitash, T. D. (2012), "Financing of health care system in Ukraine: tendencies and reforming", Mekhanizm rehuliuvannia ekonomiky, vol.1, pp. 164-169.

20.Joint report of the WHO and the World Bank (2019), "Ukraine: A Review of Health Care Financing Reform 20162019", available at: http://www.euro.who.int/_data/ assets/pdf file/0018/425340/WHO-WB-JointReport_UKR_Full-report_Web.pdf (Accessed 5 June 2020)

21. Filshteyn, L. M. and Hokhholerynt, N. L. (2011), "Problematic issues of health care financing", Naukovi pratsi Kirovohradskoho natsionalnoho tekhnichnoho universytetu. Ekonomichni nauky, vol. 9, pp. 384-388, available at: http://www.nbuv.gov.ua/Portal/natural/ Npkntu_e/2011_20_1/stat_20_1/58.pdf (Accessed 5 June 2020).

22. Shevchenko, M.V. (2010), "Total expenditures on health care in Ukraine (according to national health accounts)", Ukraina. Zdorovia natsii, vol. 2 (14), pp. 84-88.

23. Budhdeo, S. Watkins, J. Atun, R. Williams, C. Zeltner, T. and Maruthappu, M. (2015), "Changes in government spending on healthcare and population mortality in the European union, 1995-2010: a crosssectional ecological study", Journal of the Royal Society of Medicine, vol. 108(12), pp.490-498. https://doi.org/ $10.1177 / 0141076815600907$

24. Farahani, M. Subramanian, S. V. and Canning, D. (2010), "Effects of state-level public spending on health on the mortality probability in India", Health economics, vol.19 (11), pp.1361-1376. https://doi.org/10.1002/ hec. 1557

25. Gupta, S., Verhoeven, M. and Tiongson, E.R. (2003), "Public spending on health care and the poor", Health Economics, vol. 12 (8), pp.685-696. https:// doi.org/10.1002/hec.759.

26. Jafarov, E. and Gunnarsson V. (2008), "Government Spending on Health Care and Education in Croatia: Efficiency and Reform Options", IMF Working Paper, vol. 08 (136) DOI:10.5089/9781451869958.001

27. Savedoff, W. (2007), "What Should A Country Spend On Health Care?", Health Affairs, vol. 26 (4), pp.962-970, DOI https: / /doi.org/10.1377/hlthaff.26.4.962

28. Tran, L.D. Zimmerman, F.J. and Fielding, J.E. (2017), "Public health and the economy could be served by reallocating medical expenditures to social programs", SSM - Population Health, vol. 3 (1), pp. 185-191. Стаття надійшла до редакції 05.08.2020 p. 